\title{
Atheisms: Plural Contexts of Being Godless
}

\author{
Sanjit Chakraborty ${ }^{1} \cdot$ Anway Mukhopadhyay $^{2}$
}

Accepted: 19 July 2021 / Published online: 9 October 2021

(c) The Author(s), under exclusive licence to Springer Nature B.V. 2021, corrected publication 2021

\begin{abstract}
This special issue of Sophia, titled Living without God: A Multicultural Spectrum of Atheism, deals with the intricate issue of approaching atheism-methodologically as well as conceptually - from the perspective of cultural pluralism. What does 'atheism' mean in different cultural contexts? Can this term be applied appropriately to different religious discourses which conceptualize God/gods/Goddess/goddesses (and also godlessness) in hugely divergent ways? Or would that rather be a sort of hegemonic homogenization of all possible modalities of living without God, as Jessica Frazier argues (Frazier 2013, 367)? Is my 'God' the same as yours? If not, then how can your atheism be the same as mine? In other words, this issue of Sophia raises the question: Is it not high time that we proposed a comparative study of atheism(s) alongside that of religions, rather than believing that atheism is centered in the 'Western' experience? Besides, how can we explore the modalities of atheist religiosity such as we find in Buddhism and Jainism and also, arguably, in certain forms of Hinduism, as far as the Indic traditions are concerned? How might these (re-)negotiations of atheism across the multicultural spectrum interrogate our tendency to place atheism within the context of the binary opposition of science and religion? Besides, there is a need to focus on the philosophical negotiations between atheism, theism and agnosticism and the discourses that emerge from such dialogues, including that of postsecularity.
\end{abstract}

Keywords Atheism · Multicultural $\cdot$ Agnosticism $\cdot$ Infidelity $\cdot$ Science $\cdot$ Literature Postsecularity

Sanjit Chakraborty

cogitosanjit@gmail.com

Anway Mukhopadhyay

anwaymukhopadhyay@gmail.com

1 Indian Institute of Science Education and Research Kolkata, Mohanpur, West Bengal 741246, India

2 Department of Humanities and Social Sciences, Indian Institute of Technology Kharagpur, Kharagpur 721302, West Bengal, India 
Robin Le Poidevin, while presenting atheism as 'a definite doctrine', points out the necessity to study atheism side by side with 'religious ideas', thereby establishing the methodological connection between the study of the philosophy of religion and that of atheism:

An atheist is one who denies the existence of a personal, transcendent creator of the universe, rather than one who simply lives life without reference to such a being. A theist is one who asserts the existence of such a creator. Any discussion of atheism, then, is necessarily a discussion of theism. (Le Poidevin, 1996, xvii)

However, if reviewed from a pluralist perspective, the conflation of 'theism' and 'religious ideas' becomes problematic and makes us wonder whether 'religion' is, just like 'atheism', a homogenizing signifier that fails to capture the complex nuances of various non-Western religious doctrines which often resist compartmentalizing categorizations. For instance, there are religious traditions like Advaita Vedānta that foreground some ontological centre of the universe, without seeing it as 'God'. If we accept Robert Neville's 'heuristic' definition of religion as 'the human symbolic engagement of ultimate realities in cognitive, existential, and practical ways' $(2018,3)$ and ponder over the plurality of the ways in which different religions conceive of or figure forth this 'ultimacy' (Neville, 2018, 3-5), we may begin to understand that there is a difference between this 'ultimacy' and theos as such. Hence, irreligiosity and atheism cannot be connotationally overlapping concepts or sensibilities, when the 'ultimate reality' that may be sought for or celebrated by the 'religious' person does not become conflated with God. Further, Neville's generalization may not be universally applicable, as some religions may celebrate the interconnectivity of the beings and things of the universe rather than reaching for ultimacy. Purushottama Bilimoria raises a legitimate question, 'Do all religions necessarily have to make reference to one or another conception of ultimate reality in any trans-human, transcendental form' (2003, 350)?

However, the merit of Le Poidevin's argument warrants acknowledgement. If one has to speak of a-theism, one cannot avoid speaking of theism simultaneously. Hence, the point this issue of Sophia tries to draw home is simply this: without taking into account the plural implications of 'religion' and 'theism' (and 'ultimacy'), we cannot embark on a pluralist study of atheism(s). The moment we initiate a dialogue between different models of 'atheism' or ideas and sensibilities proximate to it, we are automatically encouraging a dialogic friction between the plural notions of 'God', 'Absolute' or 'ultimacy' prevalent across the planet. To facilitate such a mode of dialogue, this issue presents pluralist negotiations with the notion of atheism and its ethical, epistemological, ontological, literary and scientific corollaries.

Noticeably, there is no single secular ideology or behavioural norm that all atheists cherish austerely, except the denial of the existence of God/gods/Great Goddess/goddesses. In Western cultures, atheists are non-religious persons, while in certain Eastern cultures, especially in religious formations such as Buddhism and Jainism, we have religious practitioners who nevertheless do not believe in the existence of supreme God/gods (Nola, 2019, 24). Many of the Western 
scholars, it appears, believe that 'atheism' developed in the Western world. While speaking of Diagoras of Melos, supposedly the 'first' atheist in ancient Greece (Nola, 2019, 24), Marek Winiarczyk tells us that the Greek word atheos 'initially did not mean atheist per se, but rather someone who was godless, immoral, heinous or, more rarely, abandoned by the gods' (2016, 129). 'It was not until Plato's Apology', he continues, that the word atheos 'actually meant atheist' (2016, 129-130). Winiarczyk further states:

It is worth adding that Jews and Christians were also called atheists, and Christians, in turn, pressed this charge not only against pagans, but also against heretics of their own religion. In my opinion, atheism perceived as 'the negation of the existence of any kind of deity or supernatural forces' did not emerge in Greece until around the year 400 BC. $(2016,130)$

While it is true that 'atheism' as a term has a European lineage, but what it connotes was not unknown to ancient India. Some Western scholars have come to appreciate the fact that the oldest form of atheism was articulated by the Cārvāka (sixth-fifth century BC) philosophers in India who believed that '.. both monistic and dualistic ontologies can be maintained without any commitment to a further ontological category of god' (Nola, 2019, 24). Thus, when viewed crossculturally, atheism seems to have multilinear genealogies and trajectories.

Michael Ruse interestingly attempts to discuss atheism outside the Eurocentric fold. Among other things, this special issue of Sophia sets out to expand and deepen the implications of such non-Eurocentric explorations of atheism. Ruse has widely explored the atheistic or quasi-atheistic sensibilities in different world religions. However, unfortunately, his wonderful multicultural exploration of atheism culminates in the assertion that the 'problem' of atheism is primarily a 'Western Christian phenomenon' and that it manifests itself most acutely in a non-Western culture when that culture comes in contact with the Western culture $(2015,186)$. If atheism is defined in such a restrictive way, then a comparative study of atheisms across the globe (outside the binary framework of science versus religion) becomes impossible. However, as Ruse's own study makes clear (2015, 169-187), a critical engagement with the 'atheistic' strains in various religious discourses across cultures may open up new vistas for understanding atheism in a broader way. This sort of broadening of the vista of atheism, naturally, culminates in broadening the domain of comparative philosophy of religion as well.

There is a conspicuous disparity between conclusive reasoning (epistemic sense) on the ontological existence of God/gods in philosophy and a testimonial belief in the existence of God/gods in religion. An analysis of atheist arguments from the perspective of the verification theory of language would uphold the merit in such arguments where an atheist reasonably denies the cosmological or ontological denotation of God/gods by underlining the argument that the definition of God/gods itself as a non-referential concept does not involve any external referent. If anyone makes a claim about an invisible dinosaur sitting in the seminar room, no one will take the issue seriously. Similarly, God's invisibility, His 
non-evidential existence or His omniscience do not prop up a successful 'communicative action' (a la Habermas); instead, these discourses hinge on a foundational error of believing in a non-existent thing by delimiting one's rationality and reasoning. Thus, theological discourse, in the eyes of the atheist, appears to be an anti-realistic one.

At the core of the human self, there is a desire to transcend the restrictive domain of the laws of nature and comprehend a sense of freedom. As Kalidas Bhattacharyya insists, religion 'originates with this sense of freedom...Religion is co-extensive and co-eternal with this sense of freedom' (Bhattacharyya, 1975, 1). This proposition gets validated in the context of the dialectical interface between the human self and nature on a scaffold of binding natural laws and the subsequent human desire of going beyond it in pursuit of trans-natural spirituality. In many religious traditions, especially in terms of the functional aspect of 'spirituality', the seeker, being an inseparable part of the chain of causality involved in natural laws, seeks to step out of nature to get rid of the roots of suffering. The Indic religions provide a variegated panorama of transcendental spirituality, sometimes involving peculiar forms of crossover between theism and atheism. In the twenty-first century, various kinds of quest for 'ultimacy' ( $a$ la Neville) have marked the multicultural milieu of spiritual seekers who have somehow tried to bypass theism while attempting to reach a transcendent point beyond the domain of existential limitations. The twenty-first century scenario of spiritual seekers is vibrant with several hidden as well as overt dialogues between theism and atheism, and these dialogues are not always bitter debates but rather sometimes follow the logic of 'diatopical hermeneutics' (Santos, 1999, 222).

Let us, now, revisit the philosophical doctrines of ancient India, as an exemplary non-Western outlook of ideating 'theism' and 'atheism'. It must be remembered that, in the Indic philosophical traditions, the āstika (orthodox)-nāstika ${ }^{1}$ (heterodox) binary does not wholly correspond to the binary of theist-atheist. The orthodox philosophical systems accept the authority of the Veda, while the heterodox systems refute it (Bilimoria, 1990, 482). The nāstika systems include Cārvāka, Buddhist and Jain philosophies, whereas the āstika systems include Vedānta, Yoga, Sāmkhya, Mīmāṃsā, Nyāya and Vaiśeșika. The three nāstika schools listed above, however, do not underpin the existence of a transcendent God and hence appear to be atheist as well as heterodox. On the other hand, Sāmkhya, though it belongs to the asstika school, is atheist (Chattopadhyaya, 1959, 363).

The atheistic stance of Sāmkhya, one of the oldest schools of Indian philosophy, introduces Prakriti as the ultimate subtle material cause of the world that remains uncaused (an unwarranted regressus ad infinitum) and, in its primal condition, is characterized by the equilibrium of the three gunas (Radhakrishnan, 2006, 260-261). Sāmkhya moves one step further to underscore the conscious Puruṣa and claim that the unity of Purușa and Prakriti leads to the creation of the universe, and that the liberation of the empirical self (jiv va) is caused by the dissociation of

\footnotetext{
${ }^{1}$ The etymology of nāstika has bearing on the master Grammarian, Pānini, in Aștādhyāȳ defining $a s t i$ and $n \bar{a} s t i$, respectively as, 'one thinks $\mathrm{x}$ is (the case)', 'one does not think $\mathrm{x}$ is (the case)'. Based on this there has been the derivation of āstika as believers in authority of the Vedas, nāstika as disbelievers in the same (Radhakrishnan, 1960, 20); later in the tradition as theism gains traction, Vedas or Śruti is replaced by Î́vara.
} 
these two, thus denying God/gods as the supreme cause of the universe and also denying God's/gods' role in the emancipation of the jīva. On the other hand, the theist Yoga philosophy attempts to comprehend infinite God as the efficient cause of the world, although, in this system, too, the material cause of the universe is called Prakriti (Radhakrishnan, 2006, 342). Advaita Vedānta is grounded in its quest for the Absolute (Para Brahman) that goes beyond the empirical self of a human being, the phenomenal world and gods or even 'God' (İśvara: a kind of empirical theos). The mode of liberation that Advaita Vedānta advocates consists of the process of realizing an eliminative transcendence, involving the emergence of the subjective knowledge (jnāna) of the absolute identity between the empirical self and the Absolute Brahman (Bhagavan Das, 1936, 170-171). The cognitive account of Advaita Vedānta underpins a solid intellectual system of underlining a trans-empirical spiritual life directed towards the Absolute by negating the reality of the mundane world and plurality of gods. The gesture of denying the plurality of gods and also denying an ultimate or absolute status to I'svara (who is operational at the level of the manifested universe), in order to experience the supreme truth (Para Brahman), can be seen as neither an atheist stance nor a theist approach. Here, the prerequisite is the trans-empirical cognition of oneness with the pure consciousness that may appear to be similar to a theist psyche's comprehension of transcendental consciousness beyond the world of phenomena-but a diversion emerges since Advaita Vedānta does not underpin the transcendental essence of God/gods. In this context, it would be interesting to focus on what Swami Vivekananda, the most celebrated Advaita Vedāntin in modern India, had to say on atheism. As Nicholas Gier reminds us, '[a]t the World Congress of Religions in 1893, Swami Vivekananda defended the atheism of Buddhism and Jainism...' $(2000,2)$. Nemai Sadhan Bose explains:

In fact, atheism for Vivekananda is not a problem. An atheist is more welcome than a believer if he only has faith in two other fundamentals. One is faith in himself. The second essential requirement is that of character. One who is dedicated to work - a karma yogin - need not necessarily, have to believe in the existence of God. (1998, 284-285)

Of course, it would be problematic to define Advaita Vedānta as an atheist doctrine, as its vision of liberation doesnot depend as much on an İsvara/God who emancipates the limited human self as on self-help in spiritual askesis, reminding one of the Buddha's advice to his disciple Ānanda: 'Ātmadīpa-bhava' [Be your own lamp to enlighten yourself] (Mishara, 2009, 449).

However, in the cases of Jainism and Buddhism, we witness a more unequivocal scenario of atheism than what we come across in Advaita Vedānta. Jainism as an atheist doctrine believes in three tenets: common-sense realism, the relativity of judgments (syādvāda) and pluralism or many-sided realities (anekāntavāda) (Matilal, 1981, 1-3). Jainism had questioned the authority of the Vedas and challenged the divinity of the gods in Hinduism (Dundas, 2002, 233-235). The discursive framework of Jain thought rests upon the apparent conviction that the supremacy of personal gods is superfluous and the transcendental Brahman is not the creator or the first cause of the universe, either. Anne Vallely notes that 'Jainism vehemently rejects the idea of a creator God, dispenses with the concept of grace, and above all 
else, valorizes self-reliance' and offers us a fresh perspective for critically revisiting the notions of "God", "atheism" and "theism", by insisting on a 'devotional structure, which rests upon, not a creator God, but a meaningful cosmos' (2013, 351). Vallely further explains: 'Its reasons for doing so evince a dramatically distinct worldview in which an omnipotent grace-bestowing God has no place' (352). Its atheism, however, paradoxically appears to be 'God-saturated', the Jain cosmos offering space for various types of 'devas' (Vallely 356-362). Yet, despite the presence of these devas, Jainism's 'devotional apparatus thrives in the absence of any transactional relationship with a God' (Vallely 365).

Moving over to Buddhism, we see a relatable situation. As Andrew Skilton notes, while Buddhism apparently accepts the devas (gods) but refutes the existence of İ́vara (God) as a transcendental divine entity and occasionally exhibits 'quasi-theism', we must not overlook its strong critique of theism (2013, 340, 343-349). Skilton focuses on Santideva's Bodhicaryāvatāra, in the ninth chapter of which 'Santideva presents his anti-theistic arguments' (2013, 343). In addition to the philosophical arguments against the existence of God in Buddhism, Skilton explores the 'non-philosophical critiques of God' in Buddhism, focusing on those verses in the Jätaka book, 'attributed to Buddhaghosa (c. fifth century CE)', which are 'representative of an established anti-theistic rhetoric that had developed during this period' $(2013,348)$. Skilton reminds us that even the ostensibly quasi-theistic entities in Mahāyāna and Vajrayāna cannot really be equated with God (2013, 349).

As Ramkrishna Bhattacharya notes, while the believers in the authority of the Vedās saw Buddhism and Jainism as nāstika doctrines, these two systems saw as $n \bar{a} s t i k a$ those who were materialists in that they did not 'believe in rebirth and the notion that the meritorious and sinful acts of previous birth would influence the course of future life' (Bhattacharya, 2011, 229). The Cārvākas, it goes without saying, would fall under this category (Frazier, 2013, 372). The Cārvākas were perceived to be atheist and irreligious (Bhattacharya, 2011, 124). Materialism, thus, seems to have been a problem for Buddhism and Jainism as well as for the theist schools. Interestingly, as Bhattacharya observes, even Sāmkhya was seen as a materialist doctrine and 'abused' like the Cārvāka doctrine (Bhattacharya, 2011, 125). Ramkrishna Bhattacharya insists that there was a pre-Cārvāka school of materialism in India. Besides, by drawing on the Mahäbhārata and the Manimekalai, he insists that these 'two schools seem to have continued to exist side by side' (Bhattacharya, 2011, 10).

Sukumari Bhattacharya notes that the intellectual scenario of India in the seventh century BCE witnessed a lot of non-conformist ideas questioning the existence of gods and the supremacy of the Vedic texts, ideas that included Ajīivika as well as Buddhist and Jain perspectives (2002, 175-177, 181). The proponents of such ideas included, among others, Maskarin Gosāla and Rudraka Ramāputra (2002, 175-176). According to Bhattacharya, the origin of such a stirring lay in doubts and queries regarding the gods, the fire sacrifices and the Vedic texts $(2002,176,181-182)$. Moving back into a more distant past, she excavates the traces of such doubts in the Vedic texts themselves and comes to the conclusion that the Vedic texts sometimes give the impression that even those who followed the Vedic teaching were troubled by the question of the ontology of the gods. Sukumari Bhattacharya claims 
that there was an indication, even in the Vedic texts, that the gods were born out of the human imagination and did not belong, really, to a supra-terrestrial realm (2002, 155).

Pūrva Mīmāmsa, an āstika doctrine, can be seen as a rationally justified theory that denied the conception of embodied gods-in Gopinātha Kavirāja's words'karma devatās'. However, they never negated the concept of 'ājān devatās', gods who are not born from the mother's womb (Kavirāja, 1983, 15-16). These 'ājān devatās' are actually invoked in the Vedic hymns. Mīmāmsa does accept devatās (plurality of gods), but their being is contingent: Purushottama Bilimoria describes it as 'effervescent mantric-effect', having even less of beingness (being-in-theworld) than what Heidegger grants to Dasein in its self-authenticating existence. Kierkegaard would have liked (the Christian) God to condescend to just that, and some like the atheist Christians would have liked to see Jesus Christ being depicted as just that, which would make for a new concept of what John Caputo ${ }^{2}$ called the hermeneuticized repetitious divine. Following Bilimoria, one may be fascinated to say that those religious/philosophical discourses which did not follow the trajectories of the predominant metaphysical ideas in the Indic traditions, grounded in the belief in some form or other of the 'Absolute' and widely discussed during and after the colonial period, have often been 'subaltern'-ized within the field of comparative study of religions (Bilimoria, 2003, 352-354). In this context, it becomes important to focus on Mīmāmsā, a philosophical system which can be seen as casting doubts on the 'reality of a supremely divine being' (Bilimoria, 2003, 353-354; Bilimoria, 1990, 482). Bilimoria thinks that even within predominantly theistic (in the sense broader than monotheistic) traditions there can be strands of atheism (or its variations in a/theism, non-theism), that sit comfortably alongside each other. They could even be in some dependent relation - as in the case of the Mīmāmsā within the Brāhmaṇical canonical canopy (smoky maṇdapa). This is so because it is Mīmāmsāa that provides the bedrock argument for the Vedās (preeminent scriptures) being authorless (apauruseya, and therefore perennial). This rejection of God is intended to block any attribution of possible authorship of the Vedās to one supreme deity; yet at the same time, the devatās, gods, are needed as functionaries to help bring to fruition expected results from the illocutionary performance of mantras and sacrificial rites. ${ }^{3}$ Bilimoria says that though it is not possible to conclusively prove that the Mīmāmsaka was an atheist, it can be insisted that the Mīmāmssaka was certainly an agnostic, "predisposed towards a deconstruction of "onto-theo-logos" of the kind that had emerged from within the broad Indian tradition...' (1990, 482).

To sum up, one can say:

Interestingly, if one interprets atheism as rejection of a primary personal creator deity, then an array of atheist schools can be included within the range of

\footnotetext{
2 John Caputo in 'Atheism, A/theology, and the Postmodern Condition' argues that 'postmodernism turns out to be not a particularly friendly environment for atheism, either, not if atheism is a metaphysical or an otherwise fixed and decisive denial of God.' (Caputo, 2007, 267).

3 We extend our sincere thanks to Purushottama Bilimoria for bringing these wonderful points to our attention.
} 
Hindu orthodoxies. . . Reality could be explained in terms of a gnostic duality of matter and spirit (Sāmkhya), a semantic structure of sound and meaning (Mīmāmsāa), different constituents of consciousness (Yoga), various kinds of atom (Vaiśeșika), ontological monism (Advaita Vedānta), or other metaphysical models. Theism was by no means central in the earliest texts of most of these schools. (Frazier, 2013, 372-373)

Ruse, too, has noted the possibly atheist or quasi-atheist tendencies within the largely theistic spectrum of Hinduism $(2015,185)$. However, as Bilimoria puts it, 'Although it is said that the Buddha remained mute on the question of the existence of God and His role in religious discourse, the avowed non-theism of his followers was an issue of some concern to many a Hindu' $(1990,497)$. Here, one might be tempted to argue that atheism has been a 'problem' ( $a$ la Ruse) even in the Indic traditions, and hence, it is fruitful to discuss the problems posed or solved by atheism across cultures before as well as after their contact with Christianity.

Keeping in mind Bilimoria's identification of the Mīmāṃsaka as an agnostic, let us now move to a brief discussion of agnosticism in general and try to comment on its place within the global panorama of non-theism. Agnosticism is generally considered an epistemic position and 'typically characterized as a view that avoids taking any firm stand in the metaphysical and theological debate between theism and atheism by maintaining that we do not, or cannot, know-or that we do not, or cannot, justifiably believe-anything regarding God's existence or non-existence' (Pihlström 2020, 1). But it is not in any way an ontological stance as it does not assert the existence of a godless world. Disbelief in or denial of the existence of God/gods could be a faith which induces one to defensively reject the existence of God/gods rather than being agonistic about God's existence. However, the agnos$\mathrm{tic}^{4}$ does not argue that God/gods do exist in another universe; instead, they believe, with indecision, that God/gods may exist. However, can we reasonably appreciate the agonistics' proclamation (God may exist in another universe), since an opposite statement (i.e. there is no other universe and God cannot exist in another universe) implies a contradiction and an atheist's challenge too? One may argue that 'God' is an irrational idea, like the concept of 'square circles' which has no logical consistency or empirical evidence. Nourishing logical impossibilities in promoting the imaginary existence of God/gods inculcates a severe error of self-contradiction. God may be seen as the supernatural unreliable counterpart of square circles, when the agnostic position slants towards atheism strongly in the way Russell's teapot analogy did or the 'teapot agnostics' do today (McGowan, 2013, 24-25). Pihlström, however, presents a new and different kind of agnostic perspective which may lend a new orientation to the debates between theism and atheism:

Now, what we wish to suggest here is that we may apply the general and intuitive idea of agnosticism to the debate over the cognitive meaningfulness of

\footnotetext{
4 The ancient Greek sophist Protagoras in his famous book, On the Gods, writes: 'Concerning the gods I am unable to discover whether they exist or not, or what they are like in form; for there are many hindrances to knowledge, the obscurity of the subject and the brevity of human life' (Guthrie 1971, 234).
} 
religious statements. . the agnostic at the meta-level maintains that we do not, or cannot, know whether religious discourse is cognitively meaningful, purportedly factual, and/or truth-apt. Or at least there is no way we could rationally resolve the matter either way. (Pihlström 2020, 4)

From a number of perspectives, Michael Ruse, in his essay in this issue, discusses the significance and utility of the agnostic position and connects it with the centrality of freedom in an authentic human life.

An argument from a liberalist atheist or agnostic position may insist on dissociating God from the issue of morality in order to get rid of the irrational practices or religious norms that have restricted human freedom. However, does atheism or agnosticism lead to amorality, in the sense of a mode of freedom unanchored in any ethical framework? In this context, it would be relevant to underscore an observation made by R. Keith Loftin:

A common misunderstanding in the debate over the connection, if any, between God and morality stems from the mistaken conflation of two distinct questions: Is God necessary for morality? and, Can a person lead a morally praiseworthy life without believing in God? The former, an inquiry into the metaphysical foundation or grounding of morality, is an important metaethical issue. The latter is an epistemological inquiry, wholly apart from the metaethical question of morality's foundation. (Loftin, 2012, 8)

Living without God, then, is not the same thing as living outside the moral domain. A person's moral intuition may function independently of the metaethical concerns about the divine or non-divine foundations of morality.

A significant number of scientists take either an atheist or an agnostic position: the growth of human knowledge for them does not depend on God's will but on human will. Logical positivism and scientific realism insist that religious statements are empirically unverifiable and hence pointless. An atheist, generally, does not only ontologically undermine the existence of God/gods, but also distrusts any theological knowledge of God/gods. Scientific discourse places God/gods under the scanner of scientific rationality. Scientific realism holds that, while theism constructs inductive inferences about the existence of God/gods, based on religious language, the whole project in fact centres round an unobservable, causally paralysed, non-scientific entity.

However, approaching science in a different, and even a bit idiosyncratic way, one may apparently find hidden parallels between critical questions in mathematics and the vexed issues of the existence/non-existence of God. Let us ask: Could we find, in the context of the number zero, any similarity between zero as a tangible representation of non-existence and the non-existence of God (a question Sudip Bhattacharyya deals with in this issue)? As we know, the definitional part of the number zero stands for a given universal class that corresponds to nothing or an empty set whose predecessor is also zero or emptiness. Logically, existence cannot be the predecessor of non-existence, just as the number 1 (one) cannot be the predecessor of the number 0 (zero). In the context of Advaita Vedānta, we may ponder over the Zero Infinite (Śūnya Brahman, Ananta Śūnya). This Zero 
Infinite operates as the primordial root of the 'Creator' as well as his creation of the existent objective world and conscious beings. The original self-expression of the Infinite Zero occurred in primordial times-when the macrocosmic formation was not even manifested within the sphere of the primaeval empty state (i.e. the voidness of all or macrocosmic voidness). Can we, then, see the Infinite Zero (the non-existence of God) as the reality (or 'ultimacy', a la Neville) that produces God-as-fiction?

When we probe into the practical aspects of atheism and theism in human life, we need to remember that a theistic or an atheistic position is not a perennial one. Human life finds itself inescapably enmeshed in a complex interweaving of the rational and the non-rational, which may occasionally result in extra-rational choices in terms of theism or atheism. Neither an atheist nor a theist point of view should be supposed to remain constant universally or for eternity. A theist may turn into an atheist, disgusted with the excesses of a theocracy; conversely, an atheist may, gradually, turn into a theist, due to circumstances that affect the deepest core of their psychological states. Besides, while rejecting organized religion, one may nevertheless retain or develop a synthetic notion of spirituality that escapes neat epistemic categorizations. In other words, the dialogue between theism and atheism is not just a matter of a tussle between opposing doctrines or epistemic and ideological positions. It, rather, often leads to more intricate, inescapable inner quarrels or even inner synthesis in a believer/non-believer. Hence, while speaking of the psychological dimensions of theism and atheism, we need to continuously underline the contingent nature of these two positions. Being sensitive to such a contingency allows us to appreciate better those sensibilities which are affiliated to neither the conventional epistemologies of theism nor those of atheism.

In this context, we need to deal with an issue that is dialogically (and even dialectically) related to atheism in the postmodern world. It is the rise of the 'postsecular' as a result of continuous dialogic collision between theism and atheism. The postsecular 'affirms a mystery that secularism denies' (Tacey, 2020, 1). As David Tacey points out:

First there is mystery, then there is no mystery, then there is. . The new phase, the postsecular ... is a cultural and personal reorientation that presupposes disorientation, and loss of the naiive faith of phase one, and the reductive rationality of phase two. It . . looks to new ways of experiencing the world, self and ultimate reality. $(2020,1)$

It would be wrong to see this simply as the return of or regression to a religious past. Rather, it is a movement towards a more integrative understanding of the world and the self, where the secular is not dropped but assimilated into a larger vision of the 'mystery'. As Tacey insists, 'Today leading philosophers are more interested in the re-emergence of the sacred after atheism' $(2020,4)$. He cites the claim of Jean-Luc Marion 'that the whole polemic about the death of God "is now outdated"... "We are no longer in an atheist society but a post-atheist one."...' (2020, 4). According to Tacey, in philosophers such as Heidegger, Derrida, Kearney, Caputo, Vattimo and Levinas, one can find strains of the postsecular 
sentiment, even though some of these thinkers may "choose to remain identified as atheists' $(2020,4)$.

However, the linear chronology of theist-atheist-post-atheist presented by Tacey may not be required to understand the complex and peculiar emergence of the sacred even within largely atheist epistemologies, if we look at atheism from a non-Western perspective. Such a perspective may sensitize us to the epistemic and ethical potential of 'atheist' religiosity. As Michael Martin has observed, '... it does not follow from the fact that atheism is not itself a religion that there are no atheistic religions' (2007, 221). Martin insists that Jainism, Buddhism and Confucianism may be seen as religious systems that can be identified as 'atheistic', even though they 'are not atheistic in the broad sense', because 'the way to spiritual salvation and the way of life specified by these religions would not seem to be affected to any major extent by eliminating all gods' (2007, 229-230). Martin insists that atheism is not necessarily anti-religious, as it may appreciate certain aspects of religion without believing in the agency of God that a religion might insist on (2007, 230). This is an important observation, since New Atheism often gives the impression that atheism is all about a long war waged against God (Bradley \& Tate, 2010, 1-2). Martin's observations make us understand that atheism, when seen cross-culturally, seems to be neither just a war nor just an anti-God movement. As Jessica Frazier insists:

$\mathrm{Th}[\mathrm{e}]$ non-confrontational Hindu axis of atheism reminds us to open up our treatment of these issues beyond the simplifications to which polemic is prone, inviting us to root debates in a more concise hermeneutic of the specific concepts and issues at stake. The debate between theism and atheism need not be hostile, and a range of options can aid reasoning individuals to make sincere and intellectually coherent choices. . . $(2013,378)$

Bracketing off 'God' for the moment, it might be argued that religiosity may be grounded, as Mircea Eliade had observed, in the category of the 'sacred' more than in the category of the divine (Eliade, 1959, 8-18). For the Jains, for instance, life is sacred, and their ethical approach to all living beings emanates from this mode of conceptualizing the sacred (Roach, 2019, 13; Vallely, 2013, 365-366; Solomon \& Higgins, 1997, 19). The devotional culture in Jainism, as analysed by Vallely, may find a resonance in the domain of the 'postsecular'. However, its world is different from the one which goes through the three phases of theism, anti-theism and postatheism. As Vallely observes, devotion in the Jain world 'emerges not from gratitude to a supreme creator, but from the felt sense that one is being called to respond to a world that... invites participation' (2013, 365-366).

This form of religious sensibility, grounded in the principle of empathetic 'participation' in the life of the world as deeply as in one's one life ('experiencing life in a relational way - as a being-with' [Vallely, 2013, 364]), may be seen as instantiating what Lata Mani calls the 'SacredSecular', a category that weds the sacred to the secular, opening up huge scope for 'contemplative cultural critique' (Mani, 2009, 1-4). Raimon Panikkar's philosophical ideas are also grounded in a notion of sacred-secularity which emerges from a dialogue between atheism and theism that is grounded in the principle of 'diatopical hermeneutics' (see the essay of John O'Neill in this issue). This special issue of Sophia raises 
the question: Will we be able to initiate a dialogue with the sacred-secular if we dynamically dialogize comparative religion and multicultural atheisms, with a focus on that mode of ethicality which is independent of God/gods? As Julian Baggini observes, 'there is nothing to stop atheists believing in morality, a meaning for life, or human goodness' $(2003,3)$. We may add that, even after erasing God from her epistemology, an atheist can conveniently pursue the sacred-secular objectives of 'meaning for life, or human goodness'. In this context, it might be useful to ponder over certain points underlined by Simon Blackburn in his essay 'Religion and Respect':

Something is regarded as sacred when it is not to be sacrificed to other things, not to be weighed in a cost-benefit analysis, not to be touched. . . . We do not have to be conventionally religious to give these things their absolute importance. If someone tramples on them, it would be quite in order to talk of desecration. $(2007,192)$

However, Blackburn also reminds us:

If too many things are regarded as sacred, we have a life surrounded and hedged by fetishes. If too few things are so regarded, we slide into a world where everything is to be bought and sold, a matter of profit and loss. There is a balance to be struck. . . $(2007,192)$

If the atheist enjoys those 'spiritual' experiences which are not grounded in the other world but rather emanate from this world - the everyday world we inhabit (Blackburn, 2007, 191)—, she will have to strike a 'balance' between a fetishistic notion of the sacred and a vicious, exclusionary logic of profit and loss in all spheres of life. Geo-culturally distant and yet attitudinally connectable, can we see the position of Blackburn as comparable to that of Mani who raises the very interesting question: 'Is a dewdrop sacred, or is it secular?' (2009, 116-124)?

Let us proclaim, once again, that, while speaking of atheism, we do need to think about the issues at stake from a postcolonial and post-Eurocentric perspective. For instance, Raymond Converse's celebration of the rational faculty of humans, in the context of celebrating atheism as 'a positive social force' (2003, 3-9, 159-161), may sound a bit problematic to the postcolonial ears which have been 'resisting' listeners (to improvise on Judith Fetterley's trope of the 'resisting reader' [Fetterley, 1978, vii-x]) to the centuries-old imperialist claim that reason defines the human ontology and hence the irrational 'natives' should not be granted the full human status. Positioning ourselves within the multicultural matrix, we need to ask ourselves: Do we not need emotive and imaginatively empathetic engagements with the (non-human as well as human) Other(s) as well as reasoning abilities - if we are to make atheism a genuinely 'positive social force'? Cannot we learn something from the atheist altruism of Buddhism and Jainism in this respect? The atheism of these religions is grounded in their focus on the exercise of the rational faculty, with a requirement of the necessity for an ethical orientation to the world at large (Vallely, 2013, 364-366; Keown, 2000, 2-3). Therefore, we would like to underline, in this context, the necessity to appreciate Gayatri Spivak's dismissal of 'the privileging of reason' which 
she sees as aligned with the imperialist discourse of the West, while at the same time emphasizing, with Bilimoria, the necessity for 'a defense of precolonial reason' (see Bilimoria, 2003, 357-358). In fact, one may be tempted to add that the dynamics of 'precolonial reason' was inclusive enough to accommodate and complement the ethical values of empathy and altruism.

Here, it also needs to be noted that, while many scholars have argued that, in its broader sense, atheism implies a refutation of the existence of anything supernatural as well as that of God (Converse, 2003, 3), in the ancient Indian 'Lokāyata' traditions, and especially in 'Indian Tantrism', as Debiprasad Chattopadhyaya observes, belief in the magical often remained intertwined with a potentially this-worldly view of life and with materialist sensibilities that refused to overestimate the other world at the cost of earthly life (1959, xxi-xxiii, 354-358). Hence, when we ponder over the diverse forms of atheism outside the West, or, even outside organized monotheisms, we might find a chaotic assemblage of sensibilities that simultaneously underscore materialist/proto-materialist (or even scientific/proto-scientific [Chattopadhyaya, 1959, 354-358]) rationality and pluralize and diversify the frameworks of 'rational' thinking. In other words, what the West understands to be reason may be different from the reason applied by the non-Westerners in different geo-historic contexts. Hence, rationality may have multiple frameworks and functions across cultures. In order to de-universalize atheism, one needs to propose a non-universalist framework of rationality as well.

Finally, let us return, once again, to the vexed issue of the co-habitation of atheism and religiosity. Such a co-habitation is not just specific to the non-Western cultural sphere. Even within the Western discourses on atheism, religiosity and atheism often get involved in a complex relationship and thus defy any simplistic conceptualization of a universal agon between them. For instance, taking issue with theological realism and rather championing radical theology, Robin Le Poidevin insists that he would offer an atheist 'picture' of the philosophy of religion which is, nevertheless, 'not an anti-religious one' (1996, xii, 111-123). Here, Le Poidevin's frames of reference are not non-Western ones such as are deployed by Martin, namely, Indic and Chinese traditions. He speaks of a non-antagonistic relationship between atheism and religiosity that seems to be very different from the one we come across in the Indic and Chinese traditions underlined by Martin. We do need to underscore the plurality of the discursive forms and frames of atheism-atheisms, in short-even in the West itself. In this context, one may be reminded of Michael Ruse's critique of the New Atheists. Ruse says, 'I am an atheist. However, the New Atheists cannot stand me' (Ruse, 2018). Again, he observes: 'Ironically, I get on better with many of my Christian interlocutors than I do with many atheists' (Ruse, 2018). A main objective of this issue of Sophia is to foreground and celebrate the plurality of atheisms within as well as outside the West. We need to highlight the differences, frictions and dialogues between multiple modes of atheism in the West as well as those between Western and non-Western atheisms or 'irreligious' and 'religious' atheisms.

Apart from looking at the multicultural spectrum of atheism, this special issue of Sophia seeks to highlight the affective dimension of atheism. How is atheist thinking intertwined with atheist feeling? How are atheists and atheism represented by literary artists? If God is seen as a fiction (Le Poidevin, 1996, 
111-123), then how does that fiction appear to be meaningful or meaningless in the context of the art of fiction-making, that is, imaginative writing? How does existentialist fiction summon human beings to simultaneously acknowledge the freedom that one obtains in a universe devoid of God and also assume the ethical responsibility that autonomy must entail, a sense of responsibility that, - as Simone de Beauvoir would say - teaches us that the 'blood of others' is also our own blood (Cournos 1948-49, 122-126)? In order to explore these issues, this special issue deals with literary as well as philosophical texts.

While atheism and theism are seen as oppositional doctrines in the domain of philosophy, in the practical world, theists and atheists do converse, and there are interesting theist responses to atheist ideas/emotions and vice versa. How and why does an atheist enjoy art created within a theist milieu? How, when and why may an atheist find a piece of religious art speaking to her meaningfully? As Blackburn insists:

There are two directions in which people look for the meaning of life. One is beyond life itself; this is the transcendent and ontological option. . . But there is another option for meaning, and for our interpretation of religious art, which is to look only within life itself. This is the immanent option. It is content with the everyday. There is sufficient meaning for human beings in the human world - the world of familiar, and even humdrum, doings and experiences. (2007, 189-190)

To put the point differently, it is outmoded for the atheist to locate-even as an act of imaginative heurism-the meaning of the world and of human life in the other world for finding something meaningful in 'religious art'. She may choose the 'immanent option' and be 'content with the everyday'. Blackburn insists that 'an atheist should not feel guilt about responding to great religious works of art', as 'their greatness lies in the domain of emotion rather than that of ontology, and... emotions are reactions to this life, to the here and now' $(2007,191)$. He emphatically underscores the essentially human content of great religious art: 'even Christians are human, and their common humanity is expressed in the greatest Christian art. And the same applies to other religions' (2007, 191).

The basic point is that the atheist's response to the creative work of a theist or vice versa need not necessarily be confrontational; it can be conversational too. This is an issue which has been taken up by Sudipta Kaviraj in this special issue of Sophia. The emotional and intellectual interactions between theist literature and an atheist's critical consciousness may open up new vistas of dialogue and negotiation between philosophy and religion, between the theist and the godless, between the votaries of reason and the interpreters of the 'intelligence of emotions' (Nussbaum, 2003, 1-3).

The re-constellations of, and polylogic frictions between Western and nonWestern atheisms would help us envisage a new horizon of godless territory which is as plurivocal as the domain of endless figurations of the Divine. The global academy has so far mainly dealt with comparative philosophy of religion. It is now time to build up exciting frameworks for the comparative study of atheisms in philosophy, literature and the sciences. The papers in this special issue of 
Sophia, the central arguments of which are briefly presented below, contribute to this enterprise in various ways.

Graham Oppy, in his paper, 'Defining "Religion" and "Atheism", raises the issue of the multiplicity involved in the definitions of these terms. He insists that, without focusing on the definitions of these terms and exploring the complexities involved therein, we cannot ask questions or start a meaningful conversation on religion, atheism and their interface. How do we envisage a meaningful dialogue on religion and atheism without knowing whether the participants in such a dialogue mean the same thing when they use these words?

Patrick Hutchings, in his paper, 'Has God Been and Gone?', addresses the issue of atheism from a global, multicultural perspective. In the context of atheism, he explores the interface between literature, philosophy, politics and religion, underlining how the shadows or remnants of God may be seen even in an apparently godless context. In the course of this broad spectrum analysis of atheism in multicultural contexts, he speaks of the emotional and intellectual aspects of the issue at stake.

Robin Le Poidevin, in 'Religious Conversion and Loss of Faith: Cases of Personal Paradigm Shift?', tries to understand to what extent Thomas Kuhn's concept of 'paradigm shifts' can be applied to the cases of religious conversion and loss of faith. Le Poidevin presents the case studies of certain philosophers who have reported significant shifts in their points of view and notices how the reflection of the incommensurability between paradigms may be noted in one's shift away from the atheist perspective.

Simon Blackburn, in 'On Being an Infidel', delineates the difference between atheism, agnosticism and infidelity. He insists that the atheists, agnostics and the theists take seriously the issue of the existence of God. On the other hand, the infidel would say that 'God' is not a concept she is bothered with at all. Blackburn also explores the cultural and political factors that make an infidel unpopular in the contemporary world.

In his essay, 'Confessions of an Agnostic: Apologia Pro Vita Sua', Michael Ruse presents a defence of agnosticism, challenging the notion that a strong position of either theism or atheism is better than the wavering position of an agnostic. He says that it can be seen as a position that is as useful and meaningful as faith or faithlessness. Ruse tells us how the agnostic's stance allows us to have a fresh outlook on human life and the world we inhabit.

John O'Neill, in his paper, 'Raimon Panikkar's Cosmotheandric Secularity, Wilber's Integral Theory: Living With and Without the Divine', presents a polylogue on theism and atheism, drawing on the works of Raimon Panikkar, Ken Wilber, Jorge Ferrer and Christopher Hareesh Wallis. O'Neill argues that these philosophers do not just offer unique perspectives for studying religion today; rather, their works may offer us a great opportunity to make the exploration of global atheism more nuanced and insightful.

Gereon Kopf's paper 'Atheism is Nothing but an Expression of Buddha-nature' explores a/theism from the philosophical perspective of the Japanese Zen master Dogen. Kopf insists that it is useful to read, or rather re-read Nietzsche from the perspective provided by Dogen, and highlights the fact that, for Dogen, all philosophical 
positions are context-specific and hence devoid of absolute truth value. As a result, in this paper there emerges a very useful and significant conversation between theism and atheism, and it indicates the way in which we can make possible a crossperspectival cross-pollination of atheist and theist discourses.

Jeffery D. Long, in 'From a Certain Point of View...: Jain Theism and Atheism', shows us how the celebration of multiple points of view in Jain epistemology can be seen as a unique methodological key to the discussion of theism and atheism. He argues that, in Jainism, a position may emerge as an atheist one from one point of view, and as a theist one from another point of view. Drawing on this, Long emphasizes the necessity to acknowledge the existence of multiple perspectives while speaking of theism and atheism, especially in a pluralist context.

Purushottama Bilimoria, in his paper 'The Missing God of Heidegger and Karl Jaspers: Too late for God; too Early for the Gods-with a Vignette from Indian Philosophy', takes up the issue of the 'missing God' in the thinking, particularly, of two existentialist philosophers: Martin Heidegger and Karl Jaspers. Bilimoria reads their scholastic approaches to transcendence from the lens of each other (as Jaspers and Heidegger were closely connected), while also drawing on global-critical philosophy of religion for a more contemporary perspective. In the final section, a comparative framework is suggested for discussing deus absconditus between Western and non-Western philosophies, thereby initiating philosophical dialogue between atheism and faith, the human and the posthuman, the divine and the postdivine.

In his essay, 'Can nāstikas taste āstika poetry? Tagore's poetry and the critique of secularity', Sudipta Kaviraj critically revisits the notions of secularity and modernity and seeks to explore how and why the atheist reader's enjoyment of theist poetry may be seen as uncontradictory or non-problematic, with reference to his personal engagement with Rabindranath Tagore's theist poetry. Kaviraj historicizes the cultural context which gave rise to Tagore's poetic world and reads or rather re-reads Tagore side by side with Weber, to look at the reason why the religious world of Tagore is still relevant to the 'secular age'. Kaviraj enunciates that his reading of Indian philosophy - especially Indian aesthetics in a religious context-has altered his understanding of 'imagination' and underlines the utility of the imaginative poetic world of a theist poet in the secular world of an atheist.

In her essay, 'Postsecularity and the Poetry of T. S. Eliot, Stevie Smith and Carol Ann Duffy', Jane Dowson takes up the issue of postsecularity in philosophical and literary contexts and explores how it plays a dynamic role in the poetry of Eliot, Smith and Duffy, in effect problematizing the binary opposition of faith and atheism. She reflects on how poetic discourse, thanks to its capacity for transcending the rational discourses of philosophy, may provide a significant context for exploring the emotive dynamics of postsecularity.

Rukmini Bhaya Nair's paper "'Do you believe in God, Doctor?" The Atheism of Fiction and the Fiction of Atheism' seeks to explore what atheism and fiction may have in common. Nair focuses on Albert Camus's Plague, a great novel that presents a society plagued by an epidemic and involves debates on theism and atheism. It upholds the connections between atheism and fiction in terms of disbelief and absurdity. Obviously, Nair's concerns find a notable resonance in the virus-ridden world today where the concepts Camus dealt with need to be revisited and interrogated afresh. Nair 
theorizes the humanism crucial in a godless universe that Camus underlined, through the lens of ordinary language philosophy and by using the tools of sociolinguistics.

Nick Trakakis, in his essay, "And therefore I hasten to return my ticket": Antitheodicy Radicalised', reads Ivan in Dostoevsky's Brothers Karamazov as an antitheodicist whose perspective may radicalize the programme of anti-theodicy. In his reading, the paradoxical nature of Ivan's gesture of accepting God but rejecting God's world is not diluted; nor is it assimilated to either a theist or an atheist framework. Trakakis explores the radical dimensions of Ivan's anti-theodicist position with reference to Albert Camus's dialectical conception of rebellion and Dostoevsky's choice of Christ over Truth.

In his essay, 'Zero-a Tangible Representation of Nonexistence: Implications for Modern Science and the Fundamental', Sudip Bhattacharyya insists that we need to explore the deeper philosophical implications of the mathematical zero and relate it to the capacity of modern science for explaining natural phenomena without grounding those explanations in a supernatural being or God. He argues that, in order to explore the points of convergence between modern science and atheist arguments or sensibilities, we can focus on the philosophical significance of zero which may be seen as a representation of non-existence, especially the non-existence of God in the present context.

Acknowledgements We heartily thank Purushottama Bilimoria, Patrick Hutchings, Saranindranath Tagore, Sherah Bloor and the entire Sophia team for their constant support during the preparation of this special issue (Living without God: A Multicultural Spectrum of Atheism) of Sophia. Besides, we would like to thank our distinguished contributors and the peer reviewers for their cooperation in the midst of this worldwide pandemic situation. Finally, we thank our colleagues, students and family members in India and elsewhere.

\section{References}

Baggini, J. (2003). Atheism: A very short introduction. Oxford University Press.

Bhattacharyya, K. (1975). Possibility of different types of religion. The Asiatic Society.

Bhattacharya, Ramkrishna. (2011). Studies on the Cārvāka/Lokāyata. Anthem.

Bhattacharya, Sukumari. (2002). Prabandhasangraha. Vol. 2. Gangchil.

Bilimoria, P. (1990). Hindu doubts about God: Towards a Mīmāṃsā deconstruction. International Philosophical Quarterly, 30(4), 481-499.

Bilimoria, A. Purushottama. (2003). What is the "Subaltern" of the comparative philosophy of religion? Philosophy East and West, 53(3), 340-366. https://www.jstor.org/stable/1400222.

Blackburn, S. (2007). Religion and respect. In L. M. Antony (Ed.), Philosophers without Gods: Meditations on atheism and the secular life (pp. 179-193). Oxford University Press.

Bose, N. S. (1998). Swami Vivekananda and the challenge to fundamentalism. In W. Radice (Ed.), Swami Vivekananda and the modernization of Hinduism (pp. 281-299). Oxford University Press.

Bradley, A., \& Tate, A. (2010). The new atheist novel: Fiction, philosophy and polemic after 9/11. Continuum.

Caputo, J. (2007). Atheism, A/theology, and the postmodern condition. In M. Martin (Ed.), The Cambridge companion to atheism (pp. 267-282). Cambridge University Press.

Chattopadhyaya, D. (1959). Lokāyata: A study in ancient Indian materialism. People's Publishing House.

Converse, R. W. (2003). Atheism as a positive social force. Algora Publishing.

Cournos, J. (1948-49). God, existentialism and the novel. The American Scholar, 18(1), 116-127. 
Das, B. (1936). Atma-Vidya, or the science of the self. In S. Radhakrishnan \& J. H. Muirhead (Eds.), Contemporary Indian philosophy (pp. 139-171). George Allen \& Unwin.

Dundas, P. (2002). The Jains (2nd ed.). Routledge.

Eliade, M. (1959). The sacred and the profane: The nature of religion. Translated into English by Willard R. Trask. Harcourt, Brace, and World.

Fetterley, J. (1978). The resisting reader: A feminist approach to American fiction. Indiana University Press.

Frazier, J. (2013). Hinduism. In S. Bullivant \& M. Ruse (Eds.), The Oxford handbook of atheism (pp. 367379). Oxford University Press.

Gier, N. F. (2000). Spiritual Titanism: Indian, Chinese, and Western perspectives. State University of New York Press.

Guthrie, W. K. C. (1971). The Sophists. Cambridge University Press.

Kavirāja, G. (1983). Paramārtha Prasanga. Pashyanti Prakashani.

Keown, D. (2000). Introduction. In D. Keown (Ed.), Contemporary Buddhist ethics (pp. 1-16). Routledge.

Le Poidevin, R. (1996). Arguing for atheism: An introduction to the philosophy of religion. Routledge.

Loftin, R. K. (2012). Introduction. In R. Keith Loftin (Ed.), God and morality: Four views (pp. 7-11). IVP Academic.

Mani, L. (2009). SacredSecular: Contemplative cultural critique. Routledge.

Martin, M. (2007). Atheism and religion. In M. Martin (Ed.), The Cambridge companion to atheism (pp. 217-232). Cambridge University Press.

Matilal, B. K. (1981). The central philosophy of Jainism (Anekāntavāda). L. D. Series 79. L. D. Institute of Indology.

McGowan, D. (2013). Atheism for dummies. John Wiley and Sons.

Mishara, N. (2009). Nītiśāsātra aur Vyavahār. Motilal Banarsidass.

Neville, R. (2018). Philosophy of religion and the big questions. Palgrave Communications, 4(126), 1-8. https://doi.org/10.1057/s41599-018-0182-9

Nola, R. (2019). Definition: Atheism. In J. W. Koterski, S. J., \& G. Oppy (Eds.), Theism and atheism: Opposing arguments in philosophy (pp. 19-33). Gale.

Nussbaum, M. C. (2003). Upheavals of thought: The intelligence of emotions. Cambridge University Press.

Pihlstrom, S. (2020). Meaning agnosticism and pragmatism. Religions, 11(302), 1-13. https://doi.org/10. 3390/rel11060302

Radhakrishnan, S. (1960). The Brahma Sütra, the philosophy of spiritual life. George Allen \& Unwin.

Radhakrishnan, S. (2006). Indian philosophy (Vol. 2). Oxford University Press.

Roach, S. C. (2019). Decency and difference: Humanity and the global challenge of identity politics. University of Michigan Press.

Ruse, M. (2015). Atheism: What everyone needs to know. Oxford University Press.

Ruse, M. (2018, September 25). I'm an atheist. But thank God I'm not a new atheist. Premier Christianity. Premierchristianity.com. https:/www.premierchristianity.com/Blog/I-m-an-atheist.-But-thankGod-I-m-not-a-New-Atheist. Accessed 19 Dec 2020.

Santos, B. de Sousa. (1999). Towards a multicultural conception of human rights. In M. Featherstone \& S. Lash (Eds.), Spaces of culture: City, nation, world (pp. 214-229). Sage.

Skilton, A. (2013). Buddhism. In S. Bullivant \& M. Ruse (Eds.), The Oxford handbook of atheism (pp. 337-350). Oxford University Press.

Solomon, R. C., \& Higgins, K. M. (1997). A passion for wisdom: A very brief history of philosophy. Oxford University Press.

Tacey, D. (2020). The postsecular sacred: Jung, soul and meaning in an age of change. Routledge.

Vallely, A. (2013). Jainism. In S. Bullivant \& M. Ruse (Eds.), The Oxford handbook of atheism (pp. 351-366). Oxford University Press.

Vasu, S. C. (1898). The Așțādhyāȳ̄ of Pāṇini. Indian Press.

Winiarczyk, M. (2016). Diagoras of Melos: A contribution to the history of ancient atheism. Translated into English by Witold Zbirohowski-Koscia. De Gruyter.

Publisher's Note Springer Nature remains neutral with regard to jurisdictional claims in published maps and institutional affiliations. 